\title{
KELIMPAHAN DAN PREVALENSI PENYAKIT KARANG DI PERAIRAN LANGARA, KONAWA KEPULAUAN, SULAWESI TENGGARA
}

\author{
Abundance and Prevalence of coral Diseases in Langara Waters, Konawe Kepulauan, \\ Southeast Sulawesi
}

\author{
Siti Hasma ${ }^{1}$, Baru Sadarun ${ }^{2}$, dan Ratna Diyah Palupi ${ }^{3}$ \\ ${ }^{1}$ Mahasiswa Jurusan Ilmu Kelautan, \\ Fakultas Perikanan dan Ilmu Kelautan, Universitas Halu Oleo. \\ Jl. H.E.A Mokodompit Kampus Hijau Bumi Tridharma Anduonohu Kendari 93232, Telp/Fax: (0401) 3193782 \\ ${ }^{2}$ Surel: sadarunbaru6@gmail.com \\ ${ }^{3}$ Surel: palupi_rd@yahoo.com
}

\begin{abstract}
Abstrak
Penyakit karang adalah gangguan terhadap kesehatan karang yang menyebabkan hilang atau rusaknya jaringan karang. Biota karang yang terinfeksi penyakit telah diidentifikasikan sebagai salah satu faktor utama yang memperburuk tutupan terumbu karang secara global. Tujuan dari penelitian ini untuk mengetahui kelimpahan dan prevalensi penyakit karang di Perairan Langara, Konawe Kepulauan, Sulawesi Tenggara. Pengambilan data dilakukan di bulan April 2018 pada tiga stasiun penelitian. Metode pengambilan data kelimpahan dan prevalensi penyakit karang menggunakan metode belt transect (transek sabuk) dengan luas area transek $350 \mathrm{~m}^{2}$, yang ditarik sejajar garis pantai. Hasil penelitian menyebutkan bahwa penyakit karang yang ditemukan di lokasi penelitian sebanyak 8 jenis [Black Band Disease (BBD), Dark Spots Disease (DSD), Ulcerative White Spots (UWS), White Band Disease (WBD), Explained Growth Anomalies (EGA), White Syndrom (WS), Bleacing (BL) dan Yellow Band Disease (YBD)]. Kelimpahan dan prevalensi penyakit karang yang tertinggi terdapat di stasiun II, dimana nilai kelimpahan yaitu $0.063 \mathrm{koloni} / \mathrm{m}^{2}$ dan nilai prevalensi yaitu $92.187 \%$. Jenis penyakit karang yang mendominasi di lokasi penelitian secara berturut-turut adalah UWS, BBD dan WS.
\end{abstract}

Kata Kunci: Kelimpahan; Penyakit Karang; Perairan Langara; Prevalensi

\begin{abstract}
Coral diseases are a disruption to coral health that causes loss and damage to coral tissue. Coral infected with the disease is one of the main factors which reduce global coral cover. This study aimd to determine the abundance and prevalence of coral diseases in Langara Waters, Konawe Islands, Southeast Sulawesi. Data collection were carried out in April 2018 in three research stations. The abundance and the prevalence data of coral diseases were collected by using the belt transect method with an area of $350 \mathrm{~m}^{2}$, and it set parallel to the coastline. The results of this study have found eight types of coral diseases in different locations, i.e. [Black Band Disease (BBD), Dark Spots Disease (DSD), Ulcerative White Spots (UWS), White Band Disease (WBD), Explained Growth Anomalies (EGA) White Syndrome (WS), Bleaching (BL) and Yellow Band Disease (YBD)]. Off the eight types of diseases, the highest abundance and prevalence of the coral disease are found at the station II which the abundance value is 0.063 colonies $/ \mathrm{m} 2$, and the prevalence value is $92.187 \%$. The type of coral disease that dominates in the study sites are UWS disease followed by BBD and WS diseases.
\end{abstract}

Keywords: Abundance; Coral Disease; Langara Waters, Prevalence

\section{Pendahuluan}

Terumbu karang sebagai ekosistem khas perairan tropis merupakan habitat berbagai biota laut untuk tumbuh dan berkembangbiak. Namun terumbu karang saat ini telah mengalami kerusakkan yang disebabkan oleh berbagai faktor seperti pengasaman laut, naiknya temperatur akibat perubahan iklim, penangkapan ikan berlebihan dan polusi.

Munculnya penyakit karang dicirikan dengan adanya perubahan warna, kerusakan dari skeleton biota karang, sampai dengan kehilangan jaringannya. Munculnya penyakit tersebut merupakan interaksi antara host atau inang dalam hal ini biota karang, agent atau pembawa dalam hal ini patogen, dan lingkungan. Beberapa penelitian mengungkapkan bahwa penurunan kualitas lingkungan perairan sangat berperan terhadap munculnya agent atau mikroorganisme pembawa patogen terhadap karang (Borger $e t$ al., 2005). Tujuan dari penelitian ini yaitu untuk mengetahui kelimpahan dan prevalensi penyakit karang di perairan Langara.

\section{Bahan dan Metode \\ Pengambilan data kelimpahan dan prevalensi penyakit karang telah}


dilaksanakan pada bulan April 2018 bertempat di perairan Langara Kabupaten Konawe, Kepulauan Sulawesi Tenggara.

Survey pendahuluan dilakukan untuk mengetahui keberadaan penyakit karang di perairan Langara. Survey dilakukan dengan menggunakan alat dasar selam dengan cara snorkeling. Survey ini bertujuan untuk melihat kondisi awal lokasi yang digunakan sebagai dasar penentuan titik lokasi penelitian.

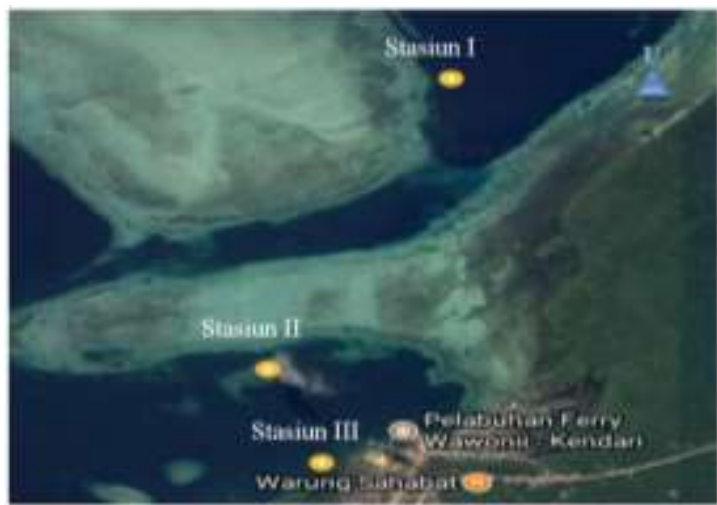

Gambar 1. Sketsa Lokasi Penelitian

Penentuan titik stasiun penelitian dilakukan dengan mengunakan metode purposif sampling. Penandaan stasiun penelitian menggunakan Global Position System (GPS) yang diambil sebanyak 3 (tiga) titik stasiun, untuk lebih jelasnya dapat dilihat pada Gambar 9. Adapun titik koordinat dari stasiun penelitian sebagai berikut :

a. Stasiun I : Stasiun pertama berada dekat dengan Pantai Kampa, bersubstrat pasir dengan titik kordinat 3058'28,7" LS $123^{\circ} 59^{\prime} 28,7^{\prime \prime}$ BT.

b. Stasiun II : Stasiun ini terletak dekat dengan jalur pelayaran kapal, bersubstrat pasir berada pada titik koordinat $04^{\circ} 00^{\prime}$ $58,7^{\prime \prime} \mathrm{LS}-122^{\circ} 58^{\prime} 57,4^{\prime \prime} \mathrm{BT}$.

c. Stasiun III : Stasiun ini terletak dekat dengan pelubuhan penyeberangan kapal domestik. Substrat yang berada di lokasi yaitu pasir berada pada titik koordinat 04 01' 28,5" LS - 122 $52^{\circ}$ '05,2" BT.

Pengambilan data lapangan penelitian meliputi pengambilan data kelimpahan penyakit karang, pengambilan data prevalensi, jenis penyakit karang, dan pengambilan data kondisi osenografi perairan. Pengambilan data kondisi osenografi perairan terdiri dari pengambilan data kecerahan, kedalaman, suhu, $\mathrm{pH}$, salinitas dan kecepatan arus.

Kelimpahan dan Prevalensi penyakit karang dihitung dengan menggunakan rumus:

Kelimpahan $\left(\right.$ Koloni $\left./ \mathrm{m}^{2}\right)=$

Total Koloni yang Terinfeksi Penyakit Luas transek sabuk $\left(\mathrm{m}^{2}\right)$

Prevalensi $(\%)=$ $\frac{\sum \text { Koloni karang yang Terinfeksi Penyakit ke-i }}{\sum \text { Total koloni karang sehat dan Terinfeksi }} \times 100 \%$

\section{Hasil dan Pembahasaan}

Berdasarkan hasil identifikasi jenis penyakit karang menyatakan bahwa jenis penyakit karang yang banyak dijumpai pada perairan Langara yaitu UWS, $B B D$, dan WS. Hal ini dikarenakan mewabahnya penyakit karang di lokasi penelitian sehingga biota karang dengan mudahnya tertular oleh mikro organisme pembawa patogen terhadap biota karang yang menyebabkan penyakit pada karang. Selain itu, penyebabkan tertularnya penyakit pada biota karang juga sangat berpengaruh terhadap pemangsa karang seperti ikan, Drupella, dan Acantaster planci.

Tabel 1. Jenis penyakit karang yang ditemukan di perairan Langara.

\begin{tabular}{clc}
\hline No. & Jenis penyakit & Jumlah (Koloni) \\
\hline 1 & Ulcerative White Spots (UWS) & 66 \\
2 & Black Band Disease (BBD) & 61 \\
3 & White Syndrom (WS) & 54 \\
4 & Dark Spots Disease (DSD) & 45 \\
5 & Bleacing & 45 \\
6 & White Band Disease (WBD) & 43 \\
7 & Explained Growth Anomalies (EGA) & 20 \\
8 & Yellow Band Disease (YBD) & 8 \\
\hline
\end{tabular}


Tabel 2. Tabel Hasil Pengukuran Kondisi Osenografi

\begin{tabular}{|c|c|c|c|c|c|c|c|}
\hline \multirow[b]{3}{*}{ Stasiun } & \multicolumn{7}{|c|}{ Kecepatan } \\
\hline & \multicolumn{2}{|c|}{ Suhu $\left({ }^{\circ} \mathrm{C}\right)$} & \multirow{2}{*}{$\begin{array}{c}\text { Kecerahan } \\
(\%)\end{array}$} & \multirow{2}{*}{$\begin{array}{c}\text { Arus } \\
\text { (m/det) }\end{array}$} & \multirow{2}{*}{$\begin{array}{c}\text { Salinitas } \\
\text { (ppt) }\end{array}$} & \multirow[t]{2}{*}{$\mathrm{pH}$} & \multirow{2}{*}{$\begin{array}{c}\text { Kedalaman } \\
(\mathrm{m})\end{array}$} \\
\hline & Permukaan & Kedalaman & & & & & \\
\hline I & 30 & 29 & 100 & 0,085 & 32 & 7 & 4 \\
\hline II & 30 & 29 & 100 & 0,081 & 34 & 7 & 4 \\
\hline III & 29 & 28 & 100 & 0,083 & 32 & 7 & 3 \\
\hline
\end{tabular}

Pemangsa karang yaitu ikan, siput dan nudibranch berpotensi sebagai vektor pada infeksi penyakit yang diakibatkan oleh bakteri (Rotjan dan Lewis, 2008). Nugues (2009) menyatakan bahwa Acropora cytherea terinfeksi brown band disease setelah dimangsa oleh Acantaster planci. Menurut Sutherland dan Ritchie (2004), penyakit karang merupakan suatu infeksi mikroba yang bersifat patogen terjadi pada karang yang pada awalnya dipengaruhi oleh faktor kondisi lingkungan yang tidak mendukung bagi pertumbuhan karang sehingga karang menjadi stres.

Hasil penelitian pada tiga titik stasiun menyatakan bahwa penyakit karang yang melimpah terdapat pada stasiun II (Gambar 1). Stasiun II nilai rerata dari kelimpahan penyakit karang yaitu $0,063 \mathrm{koloni} / \mathrm{m}^{2}$. Hal ini disebabkan karena pada stasiun ini terletak dekat dengan jalur pelayaran kapal domestik. Dengan demikian limbah buangan air kapal dapat berpengaruh terhadap munculnya mikroorganisme pembawa patogen terhadap karang. Hal ini sesuai dengan pernyataan Kuta dan Richarson (2002), menyatakan bahwa sumber pembuangan kotoran, masuknya air dari daratan, naiknya suhu perairan dan kedalaman merupakan faktor yang sangat berpengaruh terhadap timbulnya penyakit pada karang. Selain itu mewabahnya penyakit di Stasiun II juga menjadi penyebab melimpahnya penyakit yang di lokasi ini. Hal ini disebabkan koloni karang yang terdapat di stasiun II saling berdekatan dan penyakit yang ditemukan membentuk spots-spots kecil.

Stasiun I dan stasiun III memiliki nilai kelimpahan penyakit karang yang sangat rendah jika dibandingkan dengan stasiun II (Gambar 1). Adapun nilai kelimpahan penyakit karang pada stasiun I dan stasiun III yaitu $0,042 \mathrm{koloni} / \mathrm{m}^{2}$. Rendahnya kelimpahan penyakit karang yang ditemukan pada stasiun I dan stasiun III dikarenakan koloni karang yang yang tidak berdekatan dan di jumpai banyaknya patahan karang. Kondisi perairan juga menjadi faktor pendukung bagi pertumbuhan karang. Dimana parameter yang tidak mendukung pertumbuhan karang pada stasiun I dan stasiun III adalah salinitas perairan dan kecepatan arus. Dimana salinitas yaitu 32 ppt (Tabel 3) hal ini sesuai dengan pernyataan Supriharyono, dkk. (2007), bahwa salinitas air laut rata-rata untuk daerah tropis adalah 35 ppt, dan hewan karang hidup subur pada kisaran salinitas 34-36 ppt.

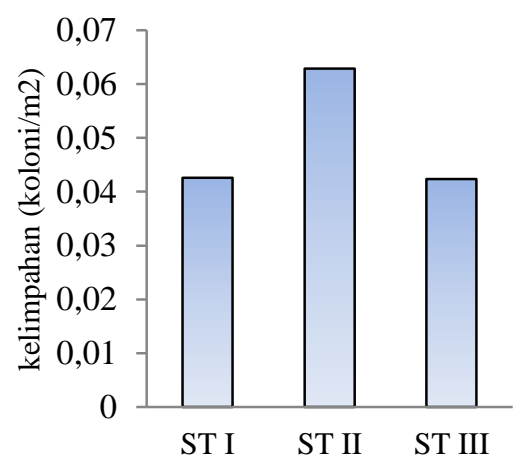

Gambar 2. Kelimpahan Penyakit Karang

Kecepatan arus sangat berpengaruh terhadap transportasi zat hara, larva, dan oksigen di perairan. Dimana kecepatan arus di lokasi penelitian yaitu stasiun I yaitu 0,085 $\mathrm{m} / \mathrm{s}$, stasiun II yaitu 0,081 dan stasiun III yaitu $0,083 \mathrm{~m} / \mathrm{s}$ (Lampiran 1). Berbeda dengan penelitian di perairan Pulau Saponda yang dilakukan oleh Hazrul (2015), kecepatan arus yang didapati di Perairan Saponda lebih cepat pergerakannya yaitu pada stasiun I $0,15 \mathrm{~m} / \mathrm{s}$, stasiun II $0,05 \mathrm{~m} / \mathrm{s}$ dan stasiun III $0,04 \mathrm{~m} / \mathrm{s}$. Sadarun, dkk. (2008) menyatakan bahwa besarnya kecepatan arus akan mempengaruhi biota karang.

Berdasarkan hasil wawancara kepada salah satu warga yang pekerjaan sehariharinya adalah sebagai nelayan, menyatakan bahwa penangkapan ikan dengan cara mengebom, mengunakan potas dan sianida masih dilakukan hingga sekarang walaupun jumlah penggunaannya sudah berkurang. Hal tersebut juga sangat berpengaruh terhadap 
hamparan tutupan terumbu karang di lokasi penelitian.

Penyakit karang juga muncul akibat aktifitas pengeboman. Aktivitas pengeboman dapat mengakibatkan luka pada karang yang nantinya dapat mengurangi sistem imun sehingga karang mudah terinfeksi mikroorganisme pembawa patogen. Santavy (2005), menyatakan bahwa ketika terumbu karang mengalami luka pada bagian koloninya maka karang akan mengeluarkan lendir dan mengalami stres. Luka dan stres tersebut menyebabkan virus dan bakteri mudah menyerang biota karang.

Jumlah koloni karang yang terinfeksi penyakit adalah 351 koloni karang, dari jumlah total koloni karang yang diteliti adalah 409 koloni karang. sehingga nilai prevalensinya adalah $86 \%$. Nilai prevalensi penyakit karang yaitu $86 \%$ lebih tinggi jika dibandingkan dengan penelitian di perairan kasilampe (Cilly, 2017). Hal tersebut terjadi dapat dikarenakan banyaknya aktivitas pengeboman yang dapat menyebabkan luka pada karang sehingga dapat menurunnya sistem imun pada biota karang, sehingga mikroorganisme pembawa patogen dapat dengan mudah menginfeksi karang. Hal ini sesuai dengan pernyataan Santavy (2005), menyatakan bahwa ketika terumbu karang mengalami luka pada bagian koloninya maka karang akan mengeluarkan lendir dan mengalami stres. Luka dan stres tersebut menyebabkan virus dan bakteri mudah menyerang biota karang.

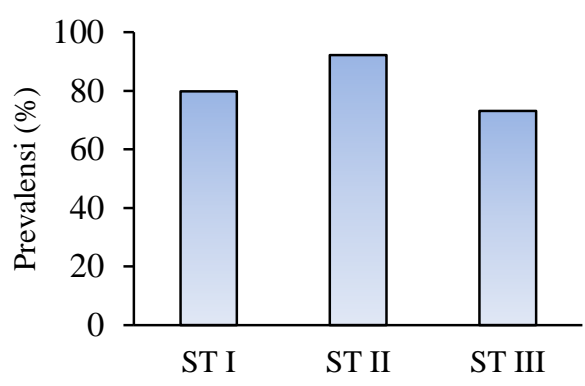

Gambar 3. Prevalensi Penyakit Karang.

Penyakit yang paling tinggi prevalensinya dari ketiga stasiun yang ditemukan di perairan Langara yaitu terdapat pada stasiun II, kemudian pada stasiun I dan terendah terdapat pada stasiun III (Gambar 2). Dominansi penyakit karang yang terdapat pada perairan Langara yaitu Ulcerative White Spots (UWS), Black Band Disease (BBD) dan
White Syndrom (WS), dengan jumlah diatas 50 koloni karang yang ditemukan terinfeksi dilokasi penelitian.

Jenis penyakit karang yang tertinggi yaitu UWS dengan jumlah koloni karang yang terinfeksi yaitu 66 koloni dan di jumpai di tiga titik stasiun penelitian. Ciri-ciri UWS yaitu munculnya lingkaran-lingkaran kecil bewarna putih dan tidak beraturan pada permukaan karang (Gambar 3). Hal ini sesuai dengan pernyataan Hazrul, dkk. (2016), menyatakan bahwa Penyakit UWS adalah kehilangan jaringan fokal karang yang diakibatkan non predasi atau bukan karena pemangsaan hewan lain. Ciri-ciri penyakit ini adalah terdapat lingkaran-lingkaran kecil berwarna putih dengan diameter 2-3 $\mathrm{mm}$, terpisah-pisah dan menyebar pada permukaan koloni.

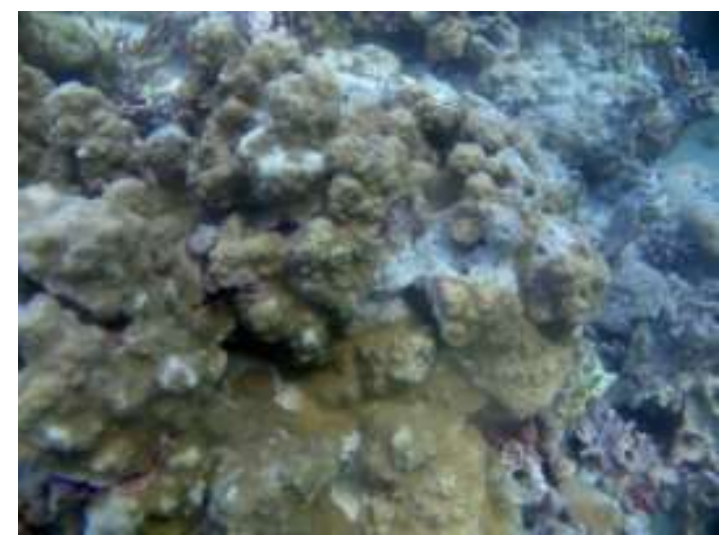

Gambar 4. Karang yang terinfeksi Penyakit

Menurut (Teasdale, 2009; Iqbal, 2014). Penyebab penyakit UWS ialah adanya penghambatan pertumbuhan bakteri disebabkan oleh beberapa faktor, salah satunya yaitu terjadinya kompetisi antara bakteri simbion karang dengan isolat bakteri karang terserang penyakit UWS untuk mendapatkan ruang dan nutrisi yang digunakan untuk pertumbuhan.

BBD adalah jenis penyakit karang terbanyak kedua dengan jumlah koloni karang yang terinfeksi yaitu 61 koloni. BBD dicirikan dengan munculnya garis hitam pada permukaan karang dan menyebar dan memengsa jaringan karang yang masih sehat, permukaan karang yang sudah terinfeksi BBD akan mengalami kematian yang ditandai dengan hilangnya jaringan karang dan memiliki perbedaan yang sangat signifikan antara jaringan karang yang sudah terinveksi dan jaringan karang yang belum terinveksi. 
Hal ini sesuai dengan pernyataan Antonius (1970), bahwa BBD dicirikan oleh suatu cincin gelap yang memisahkan antara jaringan karang yang masih sehat dengan rangka karang Siringoringo (2007).

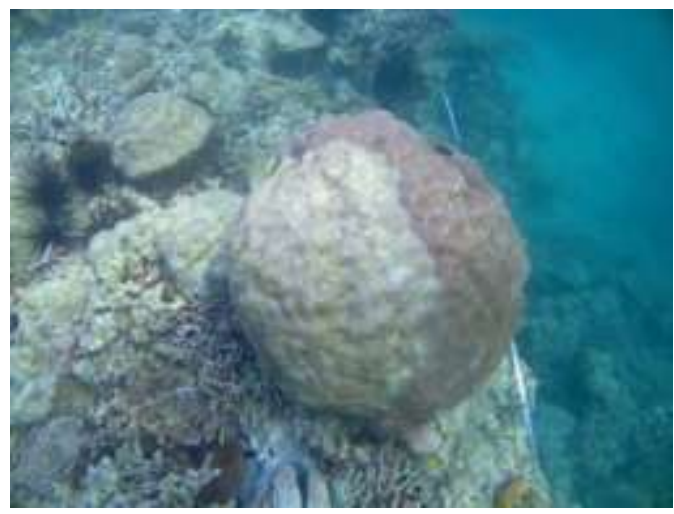

Gambar 5. Karang yang terinfeksi Penyakit Black Band Disease (BBD)

Ulcerative White Spots (UWS)

WS adalah jenis penyakit karang terbanyak yang di jumapai setelah UWS dan BBD. Sebanyak 54 koloni karang yang terinfeksi oleh WS. WS adalah penyakit karang yang dicirikan dengan munculnya bercak putih yang tebal dan tidak beraturan dan menyebar pada permukaan karang (Gambar 5).

Menurut Willis, at. al. (2004), penyebab penyakit ini masih belum diketahui. Sedangkan Menurut Redding (2013), pengaruh nitrogen menyebabkan terjadinya penyakit sindrom putih (White Syndrom) pada karang porites selain nitrogen perubahan iklim yang menyebabkan kenaikan suhu permukaan air laut menyebabkan terjadinya pengasaman laut yang mempengaruhi pertumbuhan karang. Karang cenderung memiliki respon yang lebih tanggap terhadap perubahan suhu perairan. Respon yang terjadi terlihat hilangnya pigmen warna yang terdapat pada karang. Kehilangan pigmen warna ini menyebabkan kematian massal karang.

Penyakit karang yang tertinggi yang di temukan di lokasi penelitian setelah UWS, BBD dan WS adalah DSD dan Bleacing. Jenis penyakit ini menginfeksi 45 koloni karang di lokasi penelitian. Penyakit DSD dicirikan dengan munculnya garis berwarna ungu pada permukaan karang (Gambar 6). Hal ini sesuai dengan pernyaraan Siringoringo (2007), menyatakan bahwa warna ungu gelap ke coklatan atau kelabu dari jaringan tersebut sering melingkar pada permukaan, tapi dapat juga dijumpai bentuk yang tidak beraturan pada permukaan koloni (bercak warna ungu terang terlihat pada pemutihan koloni).

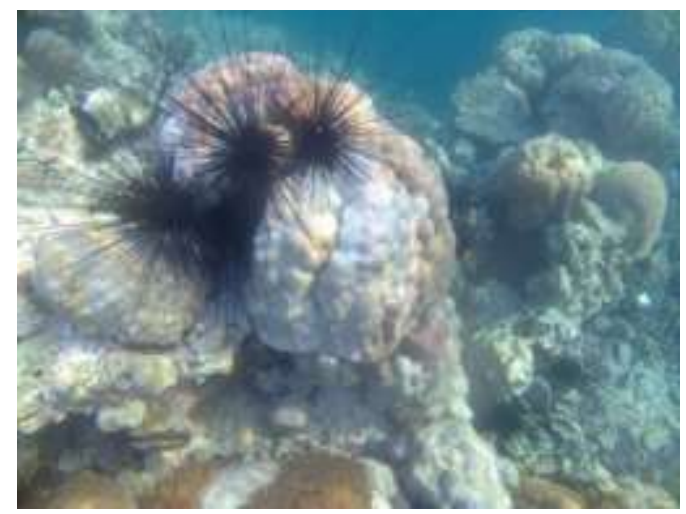

Gambar 6. Karang yang Terinfeksi Penyakit White Syndrom (WS)

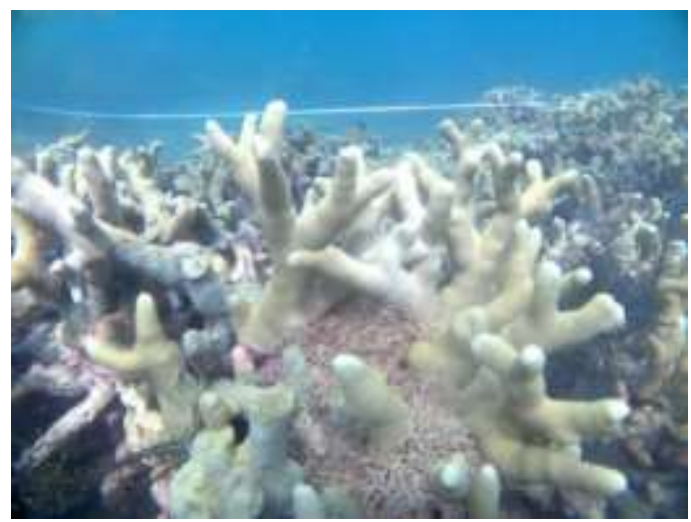

Gambar 7. Karang yang Terinfeksi Penyakit Dark Spots Disease (DSD)

Bleacing adalah peyakit karang yang dicirikan dengan munculnya perubahan warna pada permukaan karang menjadi warnah putih dan tidak. Hal tersebut terjadi dikarenakan terpisahnya atau keluarnya alga yang bersimbiosis dengan karang yaitu zooxanthellae dari jaringan epidermis karang (Gambar 7). Hal ini sesuai dengan pernyataan Walkinson (2000), yang menyatakan bahwa Bleacing adalah terpisahnya alga yang bersimbiosis (zooxanthellae) dari induk karang. Bleacing juga dapat disebabkan adanya pemangsa Acanthaster planci yang terdapat pada lokasi penelitian.

WBD adalah penyakit karang dengan jumlah koloni yang terinfeksi adalah 43 koloni dicirikan dengan munculnya garis atau pita berwarna putih pada permukaan koloni karang (Gambar 8). WBD merupakan penyakit yang memiliki kesamaan dengan BBD namun yang membedakan antara dua penyakit ini yaitu terdapat di bandnya. Penyebab terjadinya 
WBD, masih belum banyak diketahui, namun sudah ditemukan adanya kumpulan bakteri pada jaringan karang yang mampu meluas dari satu koloni ke koloni lainnya. Pada saat ini, para peneliti masih belum mampu mengidentifikasi peranan mikroorganisme yang ada pada jaringan karang yang terkena penyakit tersebut (Richardson, 1998).

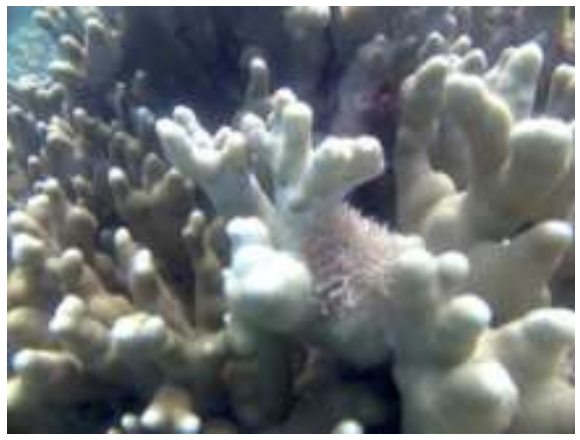

Gambar 8. Karang yang Terinfeksi Penyakit Bleacing

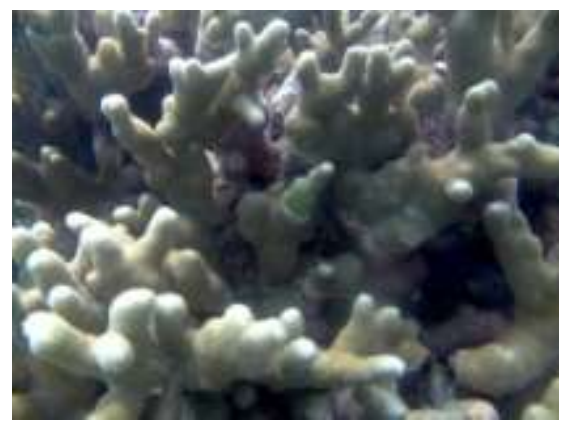

Gambar 9. Karang yang Terinfeksi Penyakit White Band Disease (WBD)

EGA adalah jenis penyakit karang yang di temukan di lokasi penelitian dengan jumlah koloni yang terinfeksi adalah 20 koloni karang. EGA dicirikan dengan hilangnya jaringan pada permkaan karang yan terinfeksi oleh penyakit EGA. Pada lokasi penelitian penyakit ini banyak dijumpai pada jenis karang Acropora. Menurut Aldyza dan Afkar (2015), bahwa permukaan karang yang terinfeksi penyakit EGA terlihat berbeda dari jaringan sehat, dan kelainan ini disebut juga dengan tumor. Penyebab perbedaan ukuran belum diketahui secara pasti. Umumnya pigmen pada jaringan yang terinfeksi EGA akan mengalami kelainan pertumbuhan.

YBD adalah jenis penyakit karang yang paling sedikit di jumpai di perairan Langara yaitu 8 koloni karang yang terinfeksi (Gambar 10). YBD dicirikan dengan munculnya bercak berwarna kuning di permukaan koloni karang dan menyebar hingga menyebabkan kerusakan pada jaringan karang. Cervino et al. (2004), menyatakan Bahwa patogen yang diduga menyebabkan penyakit pita kuning ialah bakteri Vibrio, khususnya $V$. alginolyticus dan $V$. harveyi. Akibat yang ditimbulkan oleh infeksi YBD pada karang yaitu tingkat pertumbuhan yang lambat, penurunan biomassa dan kemampuan koloni karang untuk bereproduksi menjadi menurun (Dona et al. 2008).

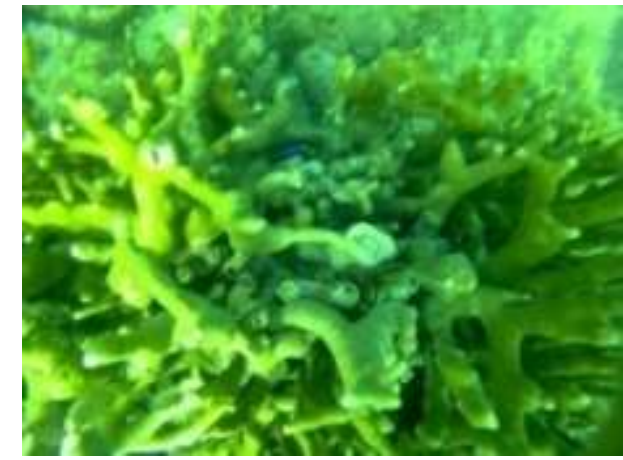

Gambar 10. Karang yang Terinfeksi Penyakit Explained Growth Anomalies (EGA)

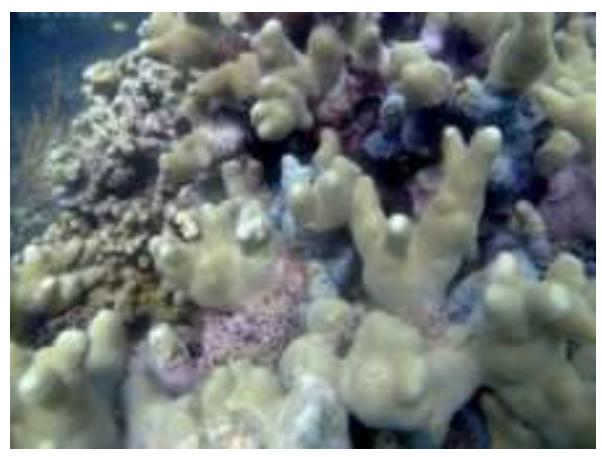

Gambar 11. Karang yang Terinfeksi Penyakit Yellow Band Disease (YBD)

\section{Simpulan}

Berdasarkan hasil penelitian di perairan Langara ditemukannya 8 jenis penyakit karang yaitu: Black Band Disease (BBD), Dark Spots Disease (DSD), Ulcerative White Spots (UWS), White Band Disease (WBD), Explained Growth Anomalies (EGA), White Syndrom (WS), Bleacing (BL), dan Yellow Band Disease (YBD). Kelimpahan dan prevalensi penyakit karang yang tertinggi terdapat pada stasiun II dengan penyakit karang yang mendominasi adalah Ulcerative White Spots (UWS), Black Band Disease (BBD) dan White Syndrom (WS). 


\section{Daftar Pustaka}

Aldyza N. Dan Afkar. 2015. Analisis Genus Dan Penyakit Karang Di Perairan Pulau Tuan Kecamatan Peukan Bada Kabupaten Aceh Besar. Jurnal Biotik. Vol. 3, No. 2. Hal 107-115.

Cervino, J.M., Hayes, R.L., Polson, S.W., Polson, S.C., Coreau, TJ., Martinez, RJ., \& Smith, G.W 2004. Relationship of Vibrio Species Infection and Elevated Temperatures to Yellow Blotch/Band Disease in Caribbean Corals. Applied And Environmental Microbiologt, p. 6855-6864.

Cilly. 2017. Prevalensi dan Jenis Penyakit pada Koloni Karang Sceleractinia di Perairan Kassilampe Kota Kendari Sulawesi Tenggara. Skripsi FPIK UHO.

Dona RA, Cervino JM, Goreau TJ, Bartels E, Hughen K, Smith GW, Dona A. 2008. Coral Yellow Band Disease; Current Status in the Carribean, and Links to New Indo-Pacific Outbreaks. Proceedings of the 11th International Coral Reef Symposium; 2008 Jul 7-11; Ft. Lauderdale, United States. Florida (US): ICRS 1:239-243.

Hazrul, Palupi, R.D dan Ketjulan, R. 2016. Identifikasi Penyakit Karang (Scleractinia) Di Perairan Pulau Saponda Laut, Sulawesi Tenggara. Jurnal Sapa Laut. Vol. 1(2) : 32-41.

Kuta KG and LL Richardson. 2002. Ecological aspects of Black Band Disease of corals, relationship between disease incidence and environmental factors. Coral

Nugues M.M, Bak R.P.M (2009). Brownband syndrome on feedingscars of the crown-of-thorn starfish Acanthaster planci. CoralReefs 28:507-510.

Redding JE, Myers-Miller RL, Baker DM, Fogel M, Raymundo LJ, Kim K. 2013. Link between sewage-derived nitrogen pollution and coral disease severityin Guam. Marine Pollution Bull etin.

Richardson, L.L. 1998. Coral diseases: What is really known? Trends in Ecology and Evolution 13 : 438-443.

Rotjan, R.D and Lewis, S.M. 2008. Impect of Coral Predators on Tropical Reefs. Marine ecology Progress Series 367: 73-91.

Santavy, D.L. 2005. The Condition of Coral Reefs in South Florida (2000) Using Coral Disease and Bleaching as Indicators. Florida, Amerika Serikat.

Siringoringo. 2007. Pemutihan Karang dan Beberapa Penyakit Karang. Bidang Sumberdaya Laut, Pusat Penelitian Oseanografi-LIPI. Jakarta. 29-37.

Wikilson, C. 2000. Status of coral reefs of the world, Australian Institute of Marine Science, Townsville : 363 pp.

Willis, B.L., Page, C.A., Dinsdale, E, A. 2004. Coral Disease on the Great Barrier Reef In Rosenberg E, Loya Y (eds) Coral Disease and Health. 69-104. Australia: James Cook University. 